Check for updates

Cite this: RSC Adv., 2018, 8, 39222

Received 24th July 2018

Accepted 16th November 2018

DOI: $10.1039 / \mathrm{c} 8 \mathrm{ra} 06275 \mathrm{~g}$

rsc.li/rsc-advances

\section{Photoinduced nucleophilic substitution of iodocubanes with arylthiolate and diphenylphosphanide ions. Experimental and computational approaches $\uparrow$}

\author{
Liliana B. Jimenez, (D) *a Marcelo Puiatti, (D) a Diego M. Andrada, ${ }^{\text {b }}$ Federico Brigante, ${ }^{a}$ \\ Karina F. Crespo Andrada, ${ }^{a}$ Roberto A. Rossi, ${ }^{a}$ Ronny Priefer (D) ${ }^{c}$ \\ and Adriana B. Pieriniț
}

A new synthetic route to modify the cubane nucleus is reported here. Methyl-4-iodocubane-1-carboxylate (1) and 1,4-diiodocubane (2) were employed as reagents to react with arylthiolate and diphenylphosphanide ions under irradiation in liquid ammonia and dimethylsulphoxide. The reactions proceed to afford thioaryland diphenylphosphoryl- cubane derivatives in moderate to good yields. It is also found that the monosubstituted product with retention of the second iodine is an intermediate compound. Mechanistic aspects are supported by DFT calculations.

\section{Introduction}

Within the different nucleophilic substitution mechanisms known, the unimolecular radical nucleophilic substitution or $\mathrm{S}_{\mathrm{RN}} 1$ process $^{1}$ is an interesting alternative to the classical $S_{N} 2$ and $S_{N} 1$ mechanisms, with a continuously growing synthetic scope. ${ }^{1,2}$ The $\mathrm{S}_{\mathrm{RN}} 1$ reaction is a cyclic process mediated by electron transfer (eT) steps. Initiation can be spontaneous, thermal, induced by inorganic salts, electrochemically, or in most cases, photostimulated. ${ }^{1}$ When light is used, an electron can be transferred from the excited state of the nucleophile to the substrate to initiate the cycle. This event can be dissociative, which means that the carbon-halogen (C-X in Scheme 1) $\S$ bond breaks as the electron is being transferred (intermolecular dissociative eT (inter-DeT)), or can follow a two-step pathway with the formation of radical anion intermediates (eqn (1)). This latter pathway occurs preferentially when the molecules have a $\pi$-system that acts as an acceptor (Acp, Scheme 1). In the second step the intermediates, through an

aINFIQC, Departamento de Química Orgánica, Facultad de Ciencias Químicas, Universidad Nacional de Córdoba, Ciudad Universitaria, X5000HUA, Córdoba, Argentina.E-mail: ljimenez@fcq.unc.edu.ar

${ }^{b}$ Krupp-Professur für Allgemeine und Anorganische Chemie, Universität des Saarlandes, 66123 Saarbrücken, Germany

${ }^{c}$ College of Pharmacy, Western New England University, Springfield, Massachusetts 01119, USA

$\dagger$ Electronic supplementary information (ESI) available: ${ }^{1} \mathrm{H}$ NMR and ${ }^{13} \mathrm{C}$ NMR spectra of new compounds, characterization data for known compounds, and computational information. See DOI: 10.1039/c8ra06275g

\$ Prof. Adriana B. Pierini deceased.

$\S \mathrm{X}$ refers to a leaving group. Most common leaving groups used in $\mathrm{S}_{\mathrm{RN}} 1$ are: $\mathrm{I}^{-}$, $\mathrm{Br}^{-}, \mathrm{Cl}^{-},(\mathrm{EtO})_{2} \mathrm{P}(\mathrm{O}) \mathrm{O}, \mathrm{RS}\left(\mathrm{R}=\mathrm{Ar}\right.$, alkyl), ArSO, $\mathrm{ArSO}_{2}, \mathrm{PhSe}, \mathrm{Ph}_{2} \mathrm{~S}^{+}, \mathrm{RSN}_{2}(\mathrm{R}=$ $t$ - $\mathrm{Bu}, \mathrm{Ph}), \mathrm{N}_{2} \mathrm{BF}_{4}, \mathrm{R}_{3} \mathrm{~N}^{+}, \mathrm{N}^{2+}, \mathrm{N}_{3}, \mathrm{NO}_{2}$, and XHg. intramolecular dissociative eT (intra-DeT) mostly from the $\pi$ system to the $\sigma^{*} \mathrm{C}-\mathrm{X}$ bond, fragment into the radical (eqn (1)) that enter the propagation cycle (eqn (2)-(4)) plus the halide anion, as is shown in Scheme 1.

This family of reactions represents an attractive alternative to conventional reactions since they are metal-free reactions leading to high yields under mild conditions. The latter feature provides suitable conditions for the inclusion of many compatible substituents (such as alkyl, OR, SAr, $\mathrm{CF}_{3}$, NHBoc, NHCOR, $\mathrm{SO}_{2} \mathrm{R}$, among others) in substrate structure. ${ }^{1}$ Additionally, substrates with strain or steric factors which have been shown to react sluggishly or not at all by polar mechanisms, are excellent substrates towards nucleophilic substitutions involving eT steps. ${ }^{1}$ Examples recounted are those such as neopentyl, bicyclic, and polycycloalkyl bridgehead halides. ${ }^{1}$

Different heteroatom-centered anions have been used in $\mathrm{S}_{\mathrm{RN}} 1$ reactions as nucleophiles to generate a new C-heteroatom bond., ${ }^{\mathbf{1 , 2}}$ In particular, it has been demonstrated that benzenethiolate and

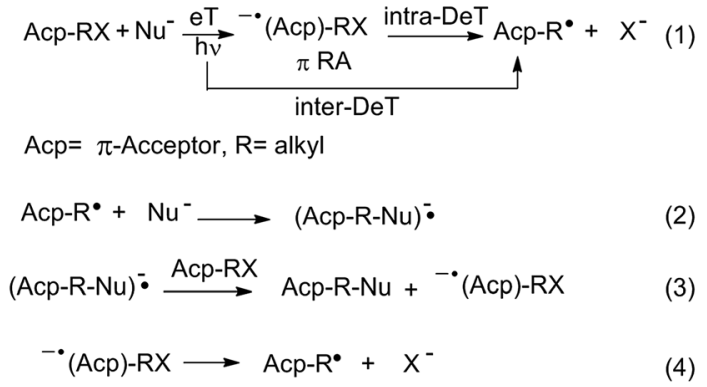

Scheme 1 Mechanism of the unimolecular radical nucleophilic substitution or $\mathrm{S}_{\mathrm{RN}} 1$ process. 
$p$-substituted benzenethiolate ions react with 1-iodoadamantane (1-IAd) under photochemical induction resulting in excellent substitution yields. ${ }^{3}$ Indeed, it has been also reported that the coupling of 1-XAd ( $\mathrm{X}=$ halogen) is possible with $\mathrm{Ph}_{2} \mathrm{P}^{-}, \mathrm{Ph}_{2} \mathrm{As}^{-}$, $\mathrm{PhSe}^{-}, \mathrm{PhTe}^{-}, \mathrm{Se}^{2-}$ and $\mathrm{Te}^{2-}$ ions. Furthermore, it has been reported that sterically hindered substrates with two leaving groups, such as 1,4-dihaloadamantanes and 4-halo-1-iodobicyclo[2.2.2] octanes, led to disubstituted and/or monosubstituted products in very good yields depending on the nature of the second halogen and the anion used under the $\mathrm{S}_{\mathrm{RN}} 1$ conditions. ${ }^{4}$ Nucleophiles as benzenethiolates and $\mathrm{Ph}_{2} \mathrm{P}^{-}$showed high substitution yields over carbanions on hindered substrates. ${ }^{1}$

In order to broaden the scope of the $\mathrm{S}_{\mathrm{RN}} 1$ reaction, we decided to explore its potential in the highly strained systems like cubanes. More than 50 years have passed since the first synthesis of the cubane carbon skeleton was reported. ${ }^{5}$ At least ten synthetic steps are needed to obtain dimethyl cubane-1,4dicarboxylate and cubane. ${ }^{6}$ Derivatives of this regular polyhedron have attracted attention due to their unexpected chemical stability ${ }^{7}$ which resulted in applications in different areas of the chemistry from medicine to nanostructure design. $^{8-10}$ Several modifications have been applied to the cubane scaffold; halogenations, photochemical solvolysis, metal-catalyzed substitutions, cross coupling substitutions based on single electron transfer using $\mathrm{Ni}$ and $\mathrm{Fe}$ as catalysts ${ }^{\mathbf{1 1}}$ and halogen-metal exchange are some examples of landmark studies. ${ }^{\mathbf{6}, 12}$ Moreover, the formation of reactive intermediates such as cubyl radicals, ${ }^{7 \boldsymbol{a}, \mathbf{1 3}, \mathbf{1 4}}$ detected also by electron paramagnetic resonance (EPR), ${ }^{13 a}$ cations $^{15}$ and anions ${ }^{16}$ was confirmed through different chemical pathways.

In this context, we have been encouraged to make a contribution to the scope of the cubane chemistry by exploring the possibility of substituting the halogens within halocubane derivatives by means of $S_{\mathrm{RN}} 1$. Clearly, the cubane skeleton does not favor both the back side attack on the traditional $\mathrm{S}_{\mathrm{N}} 2$ mechanism and the $\mathrm{S}_{\mathrm{N}} 1$ mechanism because of the considerable energy necessary to form the highly strained cubyl cation ${ }^{15}$ intermediate. Thus, the rigid strained structure of these compounds makes them interesting substrates to react by $\mathrm{eT}$ which might involve radical species with the cubyl skeleton.

The stability of both methyl-4-iodocubane-1-carboxylate (1) and 1,4-diiodocubane (2) has been studied under thermolytic conditions. ${ }^{17}$ They have not experienced any cage/rearrangement or cage opening/fragmentation reactions as is well-known to occur for iodinated cubane analogues. ${ }^{18}$ Therefore, each one was separately exposed to reactions with $\mathrm{S}$ - and P-centered anions, under eT conditions. Notably, the sulfur ${ }^{7 c, 19}$ or phosphine ${ }^{7 c}$ cubane derivatives are not a recurrent motif in the current literature. Herein, we present a thorough experimental and computational study on the transformation of cubane scaffolds via $\mathrm{S}_{\mathrm{RN}} 1$ reaction with several sulfur and phosphorous nucleophiles.

\section{Results and discussion}

\section{Experimental results}

The substrates for $\mathrm{S}_{\mathrm{RN}} 1$ reactions, methyl-4-iodocubane-1carboxylate (1) and 1,4-diiodocubane (2), were synthesized following previously published procedures. ${ }^{17}$ Both substrates are photostable since $95 \%$ and $97 \%$ of 1 and 2, respectively, were recovered after 2 hours of irradiation in absence of a nucleophile.

Scheme 2 represents the reactions of substrate 1 with arylthiolate and diphenylphosphanide ions. The photoinitiated reaction of cubane $\mathbf{1}$ in the presence of 4-methoxybenzenethiolate $\left(3^{-}\right)$led to the production of compound 7 in $61 \%$ isolated yield (Table 1 , entry 1 ). The reaction did not take place without photostimulation since $95 \%$ of the substrate was recovered after $2 \mathrm{~h}$ (Table 1, entry 2 ). Besides, as expected in the presence a $20 \% \mathrm{~mol} \mathrm{ca}$. of radical [TEMPO] and radical anion [m-DNB] scavengers (Table 1 , entries 3 and 4 ), yield of compound 7 was found to be lower ( 22 and $42 \%$, respectively). These decreasing of yields indicate that a $\mathrm{S}_{\mathrm{RN}} 1$-type mechanism could be involved. Mechanism is represented in Scheme 4.

We further explored the photoinitiated reactions of the cubane 1 with benzenethiol (4) and 4-methylbenzenethiol (5) which led to the substitution products in $75 \%$ (8) and $49 \%$ (9) yield, respectively (Table 1, entries 5 and 6). It had been already demonstrated that the $\mathrm{Ph}_{2} \mathrm{P}^{-}$ion works well as nucleophile in the $\mathrm{S}_{\mathrm{RN}} 1$-type reactions. ${ }^{1}$ The reaction with the anion $\mathbf{6}^{-}$, afforded the substituted methyl-4-(diphenylphosphino)cubane1-carboxylate (10) in $43 \%$ yield (Table 1 , entry 7 ).

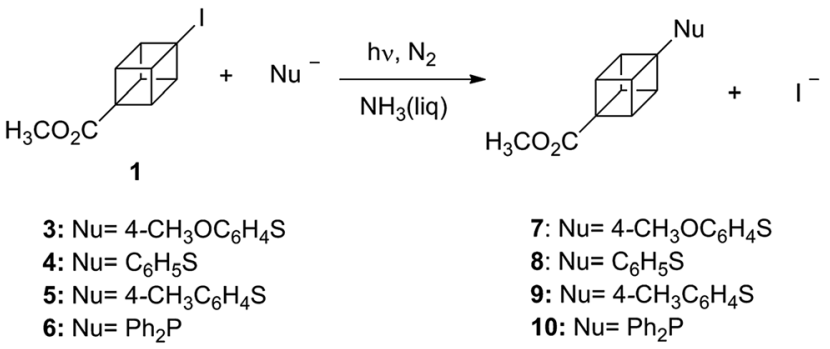

Scheme 2 Photostimulated reactions of methyl-4-iodocubane-1carboxylate (1) with aryl thiolates and $\mathrm{Ph}_{2} \mathrm{P}^{-}$ions in $\mathrm{NH}_{3(1)}$.

Table 1 Photostimulated reactions of methyl-4-iodocubane-1carboxylate (1) with 4-methoxybenzenethiolate $\left(3^{-}\right)$, benzenethiolate $\left(4^{-}\right)$, 4-methylbenzenethiolate $\left(5^{-}\right)$and diphenylphosphanide $\left(6^{-}\right)^{a}$

\begin{tabular}{|c|c|c|}
\hline Entry & $\mathrm{Nu}^{-}$ & $\begin{array}{l}\text { Product (\%), } \\
\mathrm{Nu}-\mathrm{C}_{8} \mathrm{H}_{6}-\mathrm{COOCH}_{3}\end{array}$ \\
\hline 1 & $p-\mathrm{CH}_{3} \mathrm{OC}_{6} \mathrm{H}_{4} \mathrm{~S}^{-}\left(3^{-}\right)$ & $7,61\left(78^{b}\right)$ \\
\hline $2^{c}$ & & - \\
\hline $3^{d}$ & & $7,22^{b}$ \\
\hline $4^{e}$ & & $7,42^{b}$ \\
\hline 5 & $\mathrm{C}_{6} \mathrm{H}_{5} \mathrm{~S}^{-}\left(\mathbf{4}^{-}\right)$ & 8,75 \\
\hline 6 & $p-\mathrm{CH}_{3} \mathrm{C}_{6} \mathrm{H}_{4} \mathrm{~S}^{-}\left(5^{-}\right)$ & 9,49 \\
\hline $7^{f}$ & $\mathrm{Ph}_{2} \mathrm{P}^{-}\left(6^{-}\right)$ & 10, $43^{b}$ \\
\hline
\end{tabular}

${ }^{a}$ Photostimulated reactions in $\mathrm{NH}_{3(1)}$ as solvent. Irradiation time $=2 \mathrm{~h}$. $[1]=2.9 \mathrm{mM},\left[\mathrm{Nu}^{-}\right]=14.5 \mathrm{mM}$. Isolated yields. ${ }^{b}$ The yield of the substituted product was determined by ${ }^{1} \mathrm{H}-\mathrm{NMR}$ with $p$ nitroacetophenone as internal standard. ${ }^{c}$ Dark reaction. ${ }^{d}$ To the reaction mixture was added $18 \mathrm{~mol} \%$ of TEMPO. ${ }^{e}$ To the reaction mixture was added $20 \mathrm{~mol} \%$ of $m$-dinitrobenzene ( $m$-DNB). ${ }^{f}$ Irradiation time $=60 \mathrm{~min},\left[6^{-}\right]=5.2 \mathrm{mM}$. It was isolated as the derivated acid. 


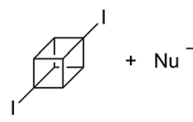

$\underset{\mathrm{NH}_{3}(\mathrm{l}) \text { or DMSO }}{\stackrel{h v}{\mathrm{~N}_{2}}}$
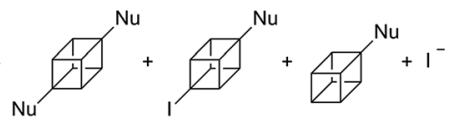

3: $\mathrm{Nu}=4-\mathrm{CH}_{3} \mathrm{OC}_{6} \mathrm{H}_{4} \mathrm{~S}$

4: $\mathrm{Nu}=\mathrm{C}_{6} \mathrm{H}_{5} \mathrm{~S}$

11: $\mathrm{Nu}=\mathrm{C}_{10} \mathrm{H}_{7} \mathrm{~S}$

6: $\mathrm{Nu}=\mathrm{Ph}_{2} \mathrm{P}$ 13a-c

a: $\mathrm{Nu}=4-\mathrm{CH}_{3} \mathrm{OC}_{6} \mathrm{H}_{4} \mathrm{~S}$

b: $\mathrm{Nu}=\mathrm{C}_{6} \mathrm{H}_{5} \mathrm{~S}$

d: $\mathrm{Nu}=\mathrm{Ph}_{2} \mathrm{P}$ c: $\mathrm{Nu}=\mathrm{C}_{10} \mathrm{H}_{7} \mathrm{~S}$

Scheme 3 Photostimulated reactions of 1,4-diiodocubane (2) with arylthiolates and $\mathrm{Ph}_{2} \mathrm{P}^{-}\left(6^{-}\right)$ions in $\mathrm{NH}_{3(1)}$ or DMSO.

We next examined the diiodocubane (2) in similar reaction conditions. A special property of interest with this substrate was the potential capability to extend symmetrically over the 1,4cubyl linear axis by two substitutions in a one-pot synthesis (Scheme 3).

The reaction indeed proceeded giving a mixture of disubstituted 1,4-bis((4-methoxyphenyl)thio)cubane (12a) and monosubstituted 4-methoxybenzenethiolcubane (14a) being formed in $48 \%$ and $10 \%$ yields, respectively (Table 2 , entry 1 ). The substrate is photostable and under non-irradiated conditions (Table 2, entry 2), or in the presence of a good electron acceptor (i.e. $m$-DNB) afforded no products (Table 2, entry 3). When the nucleophile was the benzenethiolate $\left(\mathbf{4}^{-}\right)$, reaction yields were quite similar to the ones in entry 1 , for the di- (12b) and mono-substituted (14b) cubanes with $47 \%$ and $8 \%$, respectively (Table 2 , entry 6 ).

The reactions of 2 were also performed in DMSO. This solvent was chosen because the reaction setup becomes experimentally easier. ${ }^{20}$ Under photoinductive conditions with nucleophile $3^{-}$, not only 12a and 14a were observed, the intermediate (4-iodocuban-1-yl)(4-methoxyphenyl)sulfane (13a) was also detected in yields of $27 \%, 11 \%$, and $9 \%$, respectively (Table 2 , entry 4). Aliquots of the reaction between nucleophile $3^{-}$and cubane 2 in DMSO were collected at regular time intervals to

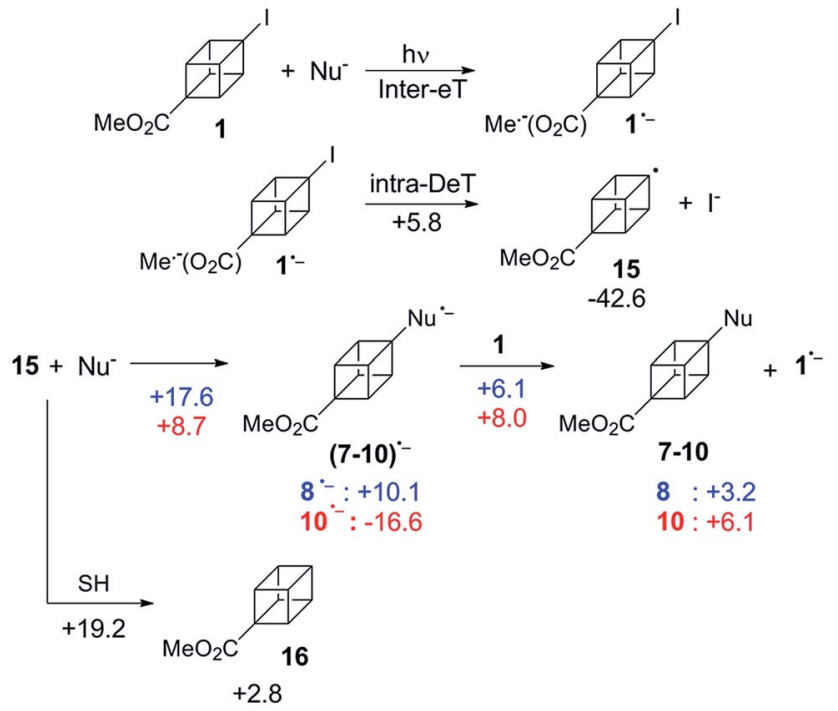

Scheme 4 Proposed mechanism for the coupling between 1 and $\mathrm{Nu}^{-}$ $\left(\mathrm{ArS}^{-}\right.$and $\mathrm{Ph}_{2} \mathrm{P}^{-}$). The numbers are the computed Gibbs energies in [kcal mol ${ }^{-1}$ ] at the PCM-[M06-2X/def2-TZVP] level of theory. In blue are the energies for $\mathrm{Nu}^{-}=\mathrm{PhS}^{-}$and in red for $\mathrm{Nu}^{-}=\mathrm{Ph}_{2} \mathrm{P}^{-}$. $\mathrm{SH}$ : the solvent considered is $\mathrm{NH}_{3}$.
Table 2 Photoinitiated reactions of 1,4-diiodocubane (2) with 4methoxybenzenethiolate $\left(3^{-}\right)$, benzenethiolate $\left(4^{-}\right)$, naphthalene-2thiolate $\left(11^{-}\right)$and diphenylphosphanide $\left(6^{-}\right)^{a}$

\begin{tabular}{|c|c|c|c|c|c|c|}
\hline \multirow[b]{2}{*}{ Entry } & \multirow[b]{2}{*}{$\mathrm{Nu}^{-}$} & \multirow[b]{2}{*}{ Solv. } & \multicolumn{4}{|c|}{ Yield (\%) } \\
\hline & & & 2 & 12 & 13 & 14 \\
\hline 1 & $p-\mathrm{CH}_{3} \mathrm{OC}_{6} \mathrm{H}_{4} \mathrm{~S}^{-}\left(3^{-}\right)$ & $\mathrm{NH}_{3(1)}$ & $<5$ & 12a, 48 & - & $14 a, 10$ \\
\hline $2^{b}$ & & $\mathrm{NH}_{3(1)}$ & $90^{c}$ & - & - & - \\
\hline $3^{d}$ & & $\mathrm{NH}_{3(1)}$ & $83^{c}$ & - & - & - \\
\hline 4 & & DMSO & - & $12 a, 27$ & 13a, 9 & $14 a, 11^{e}$ \\
\hline $5^{f}$ & & DMSO & $<5$ & $12 \mathbf{a}, 39^{g}$ & - & $14 a, 10^{e}$ \\
\hline 6 & $\mathrm{C}_{6} \mathrm{H}_{5} \mathrm{~S}^{-}\left(\mathbf{4}^{-}\right)$ & $\mathrm{NH}_{3(1)}$ & $14^{e}$ & $12 b, 47$ & - & $14 b, 8$ \\
\hline 7 & & DMSO & - & $12 b, 19$ & 13b, 15 & $14 \mathbf{b}, 8^{e}$ \\
\hline $8^{b}$ & & DMSO & 95 & - & - & - \\
\hline 9 & $\mathrm{C}_{10} \mathrm{H}_{7} \mathrm{~S}^{-}\left(\mathbf{1 1}^{-}\right)$ & $\mathrm{NH}_{3(1)}$ & $73^{c}$ & - & - & - \\
\hline 10 & & DMSO & 59 & - & $13 c, 12$ & - \\
\hline $11^{h}$ & $\mathrm{Ph}_{2} \mathrm{P}^{-}\left(6^{-}\right)$ & $\mathrm{NH}_{3(1)}$ & - & - & - & $14 d, 75^{c}$ \\
\hline
\end{tabular}

${ }^{a}$ Photostimulated reactions in $\mathrm{NH}_{3(1)}$ or $\mathrm{DMSO}_{(1)}$ as solvent. Irradiation time $=2 \mathrm{~h} .[2]_{\mathrm{NH} 3(1)}=2.8 \mathrm{mM} .[2]_{\mathrm{DMSO}}=28 \mathrm{mM},\left[\mathrm{Nu}^{-}\right]_{\mathrm{NH} 3(1)}=17 \mathrm{mM}$. $\left[\mathrm{Nu}^{-}\right]_{\text {DMSO }}=168 \mathrm{mM}$. Isolated yields. ${ }^{b}$ Dark reaction. ${ }^{c}$ Quantified by ${ }^{1} \mathrm{H}-\mathrm{NMR}$ with $p$-nitroacetophenone as internal standard. ${ }^{d} 25 \mathrm{~mol} \%$ of $m$-DNB was added to the reaction mixture. ${ }^{e}$ Yield determined by GC using the internal standard method. ${ }^{f}[2]=2.8 \mathrm{mM} .{ }^{g}$ Products were quantified by HPLC using external standard method. ${ }^{h}\left[\mathrm{Nu}^{-}\right]=$ $11.7 \mathrm{mM}$.

analyze the reaction evolution (Fig. 1). After 15 minutes, both 13a (predominant compound) and 12a were observed, as well as substrate 2. After 45 minutes, the amount of 12a and 13a were observed in almost identical quantities, however after an additional 45 minutes of irradiation, 12a was the major product and 13a appeared only in trace amounts. When the reaction was carried out in diluted conditions in DMSO (same concentration of substrate than in $\mathrm{NH}_{3(1)}$ ), product 13a was not observed after $120 \mathrm{~min}$ of reaction (Table 2 , entry 5 ). With nucleophile $\mathbf{4}^{-}$, in DMSO, the presence of the similar intermediate $\mathbf{1 3} \mathbf{b}$ was found in $15 \%$ as well as the substituted products $\mathbf{1 2 b}(19 \%)$ and $\mathbf{1 4 b}(8 \%)$ (Table 2, entry 7). As expected, without irradiation, $95 \%$ of the substrate was recovered in the reaction in DMSO (Table 2, entry 8).

Previous studies have demonstrated that naphthalene-2thiolate $\left(\mathbf{1 1}^{-}\right)$is a good nucleophile but at the same time is

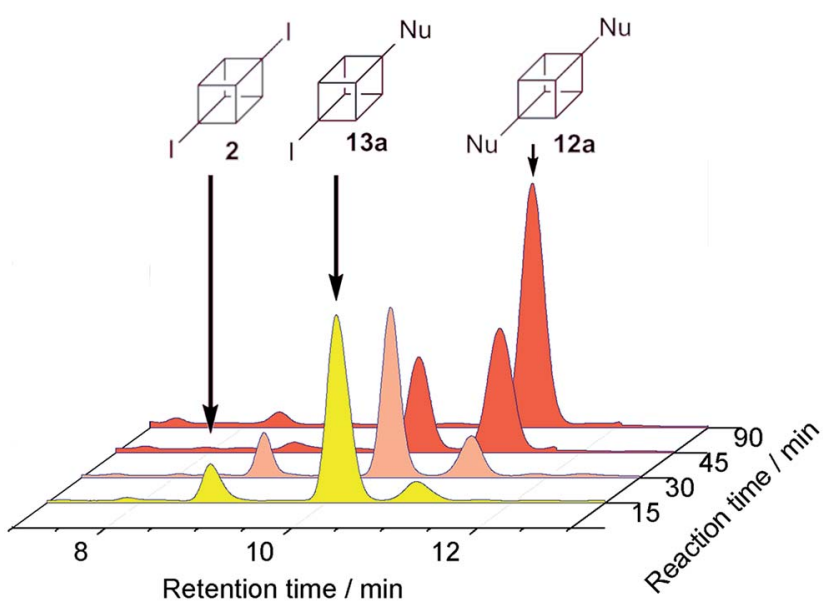

Fig. 1 Photoinduced reaction between 2 and $3^{-}$in DMSO analysed by RP-HPLC. 


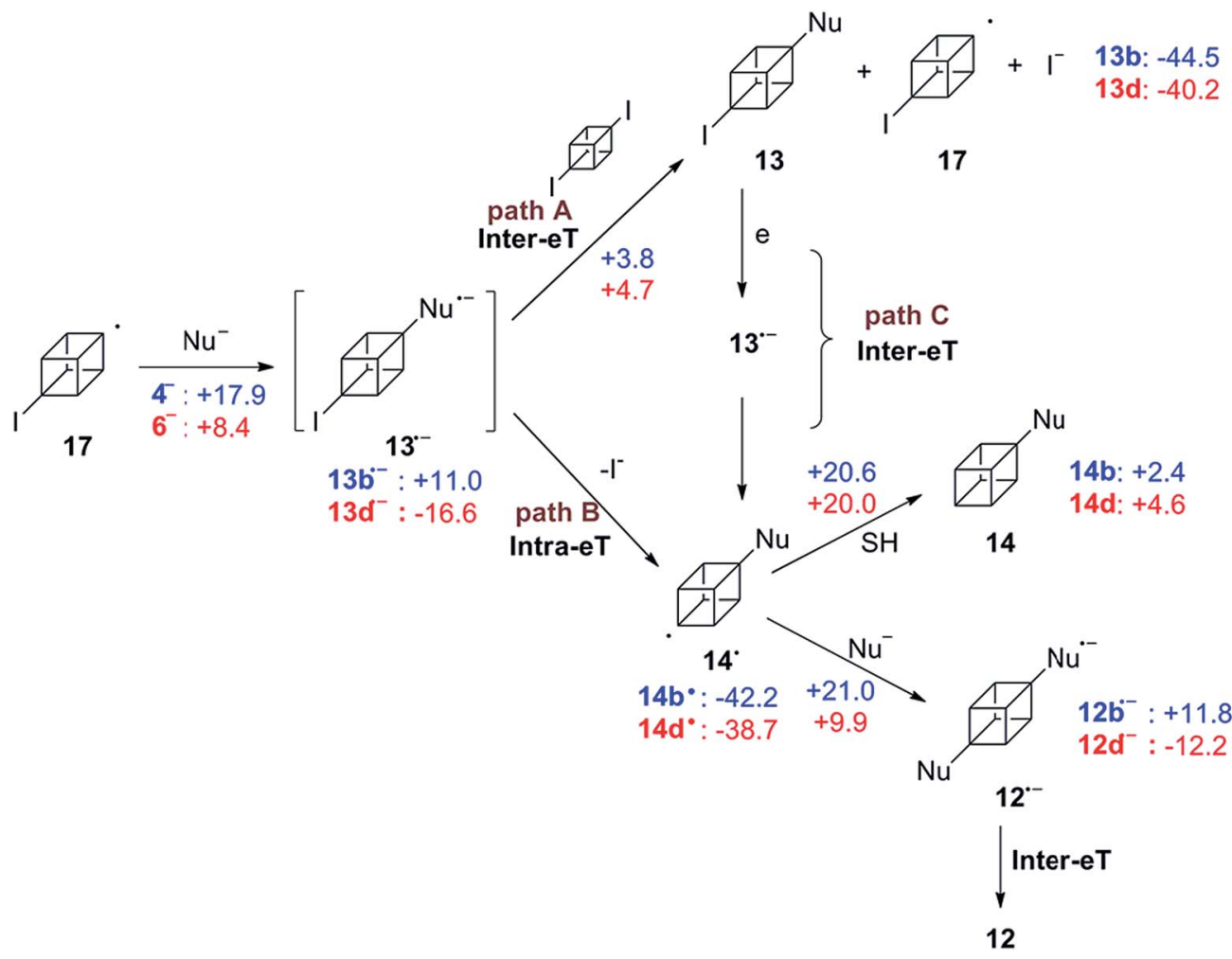

Scheme 5 Proposed mechanism for the coupling between 2/17 and $\mathrm{Nu}^{-}\left(\mathrm{PhS}^{-}\right.$and $\mathrm{Ph}_{2} \mathrm{P}^{-}$). The numbers are the computed Gibbs energies in [kcal mol $\left.{ }^{-1}\right]$ at the PCM-[M06-2X/def2-TZVP] level of theory. In blue are the energies for $\mathrm{Nu}^{-}=\mathrm{PhS}^{-}$and in red for $\mathrm{Nu}^{-}=\mathrm{Ph}_{2} \mathrm{P}^{-}$. SH: the solvent considered is $\mathrm{NH}_{3}$.

unable to transfer an electron to the aliphatic substrate in photoinduced electron transfer reactions. ${ }^{3}$ To facilitate reactions with good nucleophiles which are also poor electron donors, an entrainment compound can be added which is usually a good electron donor (reactive at initiation step) but kinetically slow for coupling as a nucleophile (non-reactive at propagation step). ${ }^{1,21}$ Aliphatic radicals, for example 1-haloadamantyl or cyclopropyl, were generated from aliphatic carbanions in $\mathrm{S}_{\mathrm{RN}} 1$-type reactions employing an entrainment agent, in $\mathrm{DMSO}^{22}$ as well as in $\mathrm{NH}_{3(1)}{ }^{23}$ as solvents. Therefore in the reactions of $\mathbf{1 1}^{-}$with $\mathbf{2}$, we employed the anions of acetone or pinacolone (3,3-dimethylbutan-2-one) as entrainments, but the coupling was still unsuccessful in $\mathrm{NH}_{3(1)}$. On the other hand, using DMSO as the solvent, and without any entrainment compound, it was possible to obtain $12 \%$ of the substituted compound with retention of the second leaving group $13 \mathrm{c}$ recovering $59 \%$ of substrate 2 .

The possibility to obtain diphosphocubane was also explored by using $\mathrm{Ph}_{2} \mathrm{P}^{-}$ion as nucleophile. The coupling did indeed occur, however, only $75 \%$ of monosubstituted-reduced product 14d was quantified by ${ }^{1} \mathrm{H}$-NMR spectroscopy. 9 This yield of the reduced product could be ascribed to the stronger reducing character of diphenylphosphanide with respect to that of the thiophenoxide ion; a difference of $c a .1 .5 \mathrm{eV}$ was estimated by DFT calculations (see ESI†).

I Compound 14d was difficult to isolated because it decomposes on silica gel as a similar reported phosphide cubanes derivatives (ref. $7 c$ ).
In order to form a new $\mathrm{C}-\mathrm{C}$ bond at the bridgehead position of the cubane nucleus, we conducted studies on the reactivity of the anion of nitromethane with $\mathbf{1}$ or $\mathbf{2}$. It is already known that this nucleophile can couple halo and dihaloadamantanes, among other halosubstrates, very efficiently but is unable to initiate the photostimulated $\mathrm{S}_{\mathrm{RN}} 1$ reaction. ${ }^{1}$ Indeed, no reaction was observed in our systems. This low reactivity for the eT nucleophilic substitution agrees with previous calculations on halo-bridgehead compounds. Pierini et al. proposed that an increase in the angular strain of aliphatic bridgehead substrates could involve a more negative reduction potential determined through their LUMO energies. ${ }^{24}$ It was also found that the 1-halocubanes studied are the halobridged substrates with lowest reactivity for photostimulated eT reactions.

\section{Calculation results}

Based on the results of the photoinduced, dark, and inhibited reactions, we propose that $\mathbf{1}$ reacts with arylsulfide and diphosphide ions by the $S_{\mathrm{RN}} 1$ mechanism, according to the mechanism proposed in Scheme 4.

Prior to the analysis of the energy profile of the proposed mechanism we carry out an evaluation of different DFT methods for the reaction between radical $\mathbf{1 5}$ and $\mathrm{SPh}^{-}$ion, to select the most appropriate one. After a careful work and analysis we decided to choose the M06-2X method with def2-TZVP basis set, which is one of the methods that gave energetic barriers closer to 
those obtained with DPLNO-CCSD(T)/cc-pVTZ. Although this last method is the best evaluated method for its accuracy, it involves a higher computational cost (see Table in ESI, section 3.3.3).

The initiation step may follow an intermolecular eT from the excited state of the $\mathrm{Nu}^{-}$to its $\mathrm{CO}_{2} \mathrm{Me} \pi$-acceptor through a nondissociative pathway with the intermediacy of $\mathbf{1}^{\cdot-}$. $\|$ The experimental results suggest an efficient intramolecular-eT step from the $\pi$-acceptor to the C-I $\sigma^{*}$ bond through the aliphatic cubyl bridge. The calculations showed that the fragmentation of the $\mathbf{1}^{--}$into the radical 15 and $\mathrm{I}^{-}$, is favored by $42.6 \mathrm{kcal} \mathrm{mol}^{-1}$. An activation barrier for this intramolecular-eT of $\sim 5.8 \mathrm{kcal} \mathrm{mol}^{-1}$ was also obtained. This value of $\Delta G \S$ for the fragmentation process could be compared with those energies (intramolecular-eT from a carbonyl $\pi$-system to a C-X $\sigma^{*}$ bond) found for other constrained systems such as norbornyl, bicyclo[2,2,2]octane or adamantyl, which are always lower than $3 \mathrm{kcal} \mathrm{mol}^{-1}$. $^{25}$ The higher energy found within the cubane system could be attributed to the lack of flexibility of the bridge which assists the intramolecular-eT process.

After the dissociation, the radical $\mathbf{1 5}$ couples with the $\mathrm{Nu}^{-}$to form the radical anion of the product $(7-10)^{\cdot-}$. According to our calculations, in terms of Gibbs energy, the process involves $10.1 \mathrm{kcal} \mathrm{mol}^{-1}$ and $-16.6 \mathrm{kcal} \mathrm{mol}^{-1}$, for $\mathrm{PhS}^{-}$and $\mathrm{Ph}_{2} \mathrm{P}^{-}$, respectively, and requires a barrier of 17.6 and $8.7 \mathrm{kcal} \mathrm{mol}^{-1}$ (in the same order) to be overcome.

The competitive reaction of $\mathbf{1 5}$ to produce the reduced product $\mathbf{1 6}$ is kinetically not favored with respect $(\Delta G \S=$ $19.2 \mathrm{kcal} \mathrm{mol}^{-1}$ ) to the coupling. Finally, an intermolecular eT from $(\mathbf{7 - 1 0})^{\cdot-}$ to $\mathbf{1}$ is responsible to continue the propagation cycle to afford products (Scheme 4). The associated Gibbs energies are slightly endergonic, i.e., 3.2 and $6.1 \mathrm{kcal} \mathrm{mol}^{-1}$ with and energy barrier of 6.1 and $8.0 \mathrm{kcal} \mathrm{mol}^{-1}$ for 8 and $\mathbf{1 0}$, respectively. Even though, the total energy released after fragmentation of the radical anion $\mathbf{1}\left(\sim 39 \mathrm{kcal} \mathrm{mol}^{-1}\right)$ could be the driving force of the eT step.**

As it happens with other aliphatic systems, ${ }^{1} \mathrm{Ph}_{2} \mathrm{P}^{-}$is expected to be a better nucleophile than $\mathrm{PhS}^{-}$. Moreover, $\mathrm{Ph}_{2} \mathrm{P}^{-}$is also a better reducing agent than $\mathrm{PhS}^{-}$, and that could justify why the yield of product $\mathbf{1 0}$ is lower than the yield of $\mathbf{8}$ (Table 1 , entries 7 and 5). When the nucleophile acts as an electron donor, the substrate reduction process is favored in $\sim 32.7 \mathrm{kcal} \mathrm{mol}^{-1}$ for $\mathrm{Ph}_{2} \mathrm{P}^{-}\left(\mathrm{Ph}_{2} \mathrm{P}^{-} / \mathrm{Ph}_{2} \mathrm{P}^{*} \approx 82.7 \mathrm{kcal} \mathrm{mol}^{-1}\right.$ or $3.58 \mathrm{eV})$ compared with $\mathrm{PhS}^{-}\left(\mathrm{PhS}^{-} / \mathrm{PhS}^{*} \approx 115.4 \mathrm{kcal} \mathrm{mol}^{-1}\right.$ or $5.05 \mathrm{eV})$.

Although our reactions were carried out under eT conditions, other possible pathways for the formation of the substituted products were evaluated. Calculations indicated

\footnotetext{
|| The photoinduced process at the initiation step corresponds to the electron transfer from the excited state of the nucleophile to the substrate. One electron photoejection is reported for nucleophiles $3^{-}, 4^{-}$and $5^{-}$when they are irradiated. ${ }^{3}$ UV-experiments of the mixture (substrate + arenethiolate ion) were carried out in order to observe if a charge transfer complex could be formed, but any new band in addition to those of the two reactants was observed. $\mathrm{UV}$-spectra of the nucleophiles $\mathbf{4}^{-}$and $\mathbf{6}^{-}$are shown in the ESI, $\dagger$ as well as of the substrate 2 .

** This process could be even more favored if the eT takes place from the excited state of $(\mathbf{7 - 1 0})^{\cdot-}$ to $\mathbf{1}$. However, due to the low concentration of these radical anions, it is difficult to determine if excited states participate in this eT step.
}

that the preferred reaction is the coupling with the nucleophile to follow a typical $\mathrm{S}_{\mathrm{RN}} 1$ pathway. Relevant energetic factors of the mechanisms explored are presented in Scheme 1-SI and Table 1-SI of the ESI. $\dagger$

Similarly, the $\mathrm{S}_{\mathrm{RN}} 1$ mechanism is proposed for substrate 2 in the photoinduced coupling reactions with arylthiolate and diphenylphosphanide ions as nucleophiles. Once radical $\mathbf{1 7}$ is formed at initiation step, it couples with the nucleophile $\mathrm{PhS}^{-}$

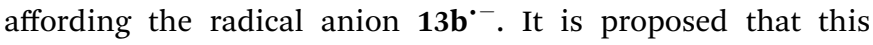
radical anion could transfer its extra electron according to two paths represented in the mechanism shown in Scheme 5. Path A depicts the process when the electron transfer is intermolecular from $13 b^{--}$to 2 to obtain the isolated compound $13 \mathbf{b}$ and the radical of the substrate which is responsible for continuing the propagation chain. In path B the electron transfer could be an intramolecular process between the $\pi$ acceptor (ArS) to the C-I $\sigma^{*}$ bond through the aliphatic cubyl bridge.

As is observed in Fig. 1, product $\mathbf{1 3 b}$ is the first compound generated at the beginning of the reaction, when the reaction keeps going, the signal of product $\mathbf{1 2 b}$ increases. At the end, $\mathbf{1 2 b}$ is the main product observed and also traces of $\mathbf{1 3 b}$. This fact could indicate that the Inter-eT (path A) should predominate

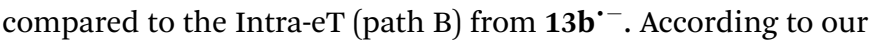
calculations, path $\mathrm{A}$ is thermodynamically favored by $2.3 \mathrm{kcal} \mathrm{mol}^{-1}$ over path B. After formation of compounds $\mathbf{1 3 b}$, these could start a new chain mechanism, involving an Inter-eT from the nucleophile to generate the radical $\mathbf{1 4} \mathbf{b}^{\circ}$ (path C) which continues to finally obtain the disubstituted or the monosubstituted-reduced compounds. We were unable to obtain experimental evidence to determine if path B does occur or not. Even when carrying out the reaction at shorter times, compound 12b was already generated as well as $\mathbf{1 3 b}$. $\dagger \dagger$

Differences with the $\mathrm{ArS}^{-}$behavior are observed when the nucleophile is $\mathrm{Ph}_{2} \mathrm{P}^{-}$(6). As it was mentioned previously, $\mathrm{Ph}_{2} \mathrm{P}^{-}$ is a good reducing agent and based on the fact that 14d, the monosubstituted-reduced compound, is the major product (Table 2, entry 11), we can postulate that path B is the most efficient electron transfer process. Similar results were observed for the rigid substrate 1,2-dichloroadamantane in its reaction with $6^{-1}$ and no disubstitution product was observed. The reduction of radical $\mathbf{1 4 d}^{\star}$ to give $\mathbf{1 4 d}$ seems to be effective and two possibilities are proposed about this formation. One possibility is that an eT occurs from the nucleophile to the radical followed by protonation in the reaction workup, which has been proposed elsewhere. ${ }^{16 a}$ The other possibility is a hydrogen abstraction from the solvent to the radical. However, liquid ammonia is not a good hydrogen donor, it can be seen from the Gibbs energy barriers informed in Scheme 5. Although the computed energies suggest that the disubstituted compounds 12b and 12d can be obtained, only the first one was observed in the experiments. Therefore, the reduction of $\mathbf{1 4 d}^{\cdot-}$

$\dagger \dagger$ Even when a low energetic barrier for the fragmentation of $\mathbf{1 3} \mathbf{b}^{--}$into radical 14 and iodide ion is expected, since we could not find the geometry of the transition state, this value is not included in the scheme. After an exploration of the reaction pathway an estimated value close to $3.8 \mathrm{kcal} \mathrm{mol}^{-1}$ was found, which is comparable to that found for the eT in path A, i.e., $3.8 \mathrm{kcal} \mathrm{mol}^{-1}$. 
via formation of an anion followed by proton abstraction during the reaction workup seems to be a plausible explanation.

\section{Conclusions}

In summary, we have developed a mild synthetic protocol to introduce thioaryl and diphenylphosphine moieties onto the cubane core via $\mathrm{S}_{\mathrm{RN}} 1$ mechanism with moderate to good yields. The mono-halosubstituted cubane derivative used (1) affords the substitution reaction of the halogen atom in moderate yields. In the case of the dihalosubstituted cubane (2), different products can be obtained depending on the conditions employed. When arenethiolate nucleophiles are used, three products can be formed, namely mono-substituted, disubstituted, and mono-substituted with retention of a halogen atom. Their relative yield can be controlled by the reaction conditions. On the other hand, the use of diphenyl phosphine as the nucleophile precursor leads only to the mono-substituted cubane derivative. This could be ascribed to the higher reduction power of this nucleophile.

The experimental evidences collected give hints of a reaction where radical species are involved. DFT calculations supports an operating $\mathrm{S}_{\mathrm{RN}} 1$ reaction mechanism where the rate determining steps are the nucleophilic coupling into the cubyl radical intermediate.

\section{Experimental}

\section{Materials}

Potassium tert-butoxide, 4-methoxybenzenethiol (3), benzenethiol (4), naphthalene-2-thiol (11) and potassium diphenylphosphide solution ( $0.5 \mathrm{M}$ in THF) are commercially available and used as received. Methyl-4-iodocubane-1-carboxylate (1) and 1,4-diiodocubane (2) were synthesized according to ref. 18. DMSO is Carlo Erba and stored under molecular sieves $(4 \AA) .{ }^{1} \mathrm{H}$ NMR and ${ }^{13} \mathrm{C}$ NMR spectra were recorded on a $400 \mathrm{MHz}$ Bruker nuclear magnetic resonance spectrometer. HR-MS were recorded on a Bruker, MicroTOF Q II equipment, operated with an ESI source in (positive/negative) mode, using nitrogen as nebulizing and drying gas and sodium formate $10 \mathrm{mM}$ as internal standard. Gas chromatographic analyses were performed on a Varian $3900 \mathrm{GC}$ with flame ionization detector on a FactorFour capillary column (VF-5 MS, $30 \mathrm{~m}, 0.32 \mathrm{~mm}, 0.25$ micron). GC-MS analyses were carried out on a Shimadzu GCMS QP5050 spectrometer, employing a $30 \mathrm{~m}, 0.32 \mathrm{~mm}, 0.25$ micron, DB-5 MS column. Irradiation was performed in a reactor equipped with two $400 \mathrm{~W}$ lamps (Philips model Master HPI-T Plus, air- and water-cooled). The Fig. SI-1 in ESI $\uparrow$ shows the spectrum of the lamps. HPLC analyses were carried out on a Waters 1525 Binary HPLC Pump connected to a Waters 2998 Photodiode Array Detector, and employing an Agilent Zorbax Eclipse XDB-C18 Analytical column $(4.6 \times 150 \mathrm{~mm}, 5 \mu \mathrm{m})$.

\section{Photoinitiated reaction in $\mathrm{NH}_{3(1)},\left(T=-33^{\circ} \mathrm{C}\right)$}

The following procedure is representative for all reactions in $\mathrm{NH}_{3(1)}$ as solvent. The equipment used is a close system, composed by a $100 \mathrm{~mL}$ three-necked round bottomed pyrexflask with a Dewar condenser, $\mathrm{N}_{2}$ inlet and $\mathrm{NH}_{3}$ inlet (see Picture SI-2 in ESI $\dagger$ ), was dried under vacuum. Liquid ammonia $(100 \mathrm{~mL})$, previously dried over Na metal, was distilled into the flask under nitrogen atmosphere (see Picture SI-3-5 in ESI $\dagger$ ). Potassium tert-butoxide and then the precursor of the nucleophile were added to the distilled ammonia. After $15 \mathrm{~min}$, the cubane substrate was dissolved $(1 \mathrm{~mL})$ in freshly distilled THF and then added to the mixture. The reaction mixture was irradiated for $120 \mathrm{~min}$. In dark reactions (without irradiation), the reaction flask was protected from light with aluminium foil and keep under $\mathrm{N}_{2}$ atmosphere (Picture SI- 6 in ESI $\dagger$ ).

After 2 hours, the mixture was quenched with an excess of $\mathrm{CH}_{3} \mathrm{I}$ and $\mathrm{NH}_{4} \mathrm{NO}_{3}$. The ammonia was allowed to evaporate, and acidic deionized water $(50 \mathrm{~mL})$ was added to the residue and extracted twice with diethyl ether $(30 \mathrm{~mL})$. The organic extract was dried $\left(\mathrm{Na}_{2} \mathrm{SO}_{4}\right)$ and filtered. The solvent was removed under reduced pressure before separation by column chromatography.

\section{Photoinduced reactions in DMSO, $\left(T=30^{\circ} \mathrm{C}\right)$}

Into a previously dried $20 \mathrm{~mL}$ Schlenk-type flask (Pyrex) equipped with nitrogen inlet and magnetic stirrer, $10 \mathrm{~mL}$ of dried DMSO stored under molecular sieves $(4 \AA)$ was added. The solvent was degassed three times under vacuum and stirring, interspersed with $\mathrm{N}_{2}$. Afterwards, potassium tert-butoxide and the anion source were added and 5 min later, the corresponding amount of cubane substrate dissolved in freshly distilled THF $(0.5 \mathrm{~mL})$ was added. The mixture was irradiated for $120 \mathrm{~min}$ then quenched by the addition of $\mathrm{CH}_{3} \mathrm{I}, \mathrm{NH}_{4} \mathrm{NO}_{3}$, and deionized water. In dark reactions (without irradiation), the reaction flask was protected from light with aluminium foil and keep under $\mathrm{N}_{2}$ atmosphere. Water at $\mathrm{pH}<3$ is added followed by extraction with diethyl ether $(3 \times 20 \mathrm{~mL})$. The ether extract was washed until no residual of DMSO remained. The organic extract was dried with $\mathrm{Na}_{2} \mathrm{SO}_{4}$, filtered, and evaporated under reduced pressure.

\section{Computational procedure}

All the calculations were performed with the Gaussian09 program ${ }^{26}$ the M06-2X DFT functional and the def2-TZVP basis set for $\mathrm{C}, \mathrm{H}, \mathrm{O}, \mathrm{S}$ and $\mathrm{P}$ were employed. The def2-TZVP ${ }^{27}$ basis set and pseudo-potential was used for I. Calculations were performed with full geometry optimization including in all cases the effect of the solvent (methanol as polar solvent) through the Tomasi's polarized continuum model (IEFPCM $^{28,29}$ as implemented in the Gaussian package. After refinement the characterization of stationary points was done by Hessian matrix calculations, with all positive eigenvalues for a minimum and only one negative eigenvalue for the TSs. The energy informed for TSs and radicals includes zero-point corrections.

\section{Methyl-4-((4-methoxyphenyl)thio)cubane-1-carboxylate (7)}

Compound was isolated by semi-preparative HPLC, employing a constant flow of $2.0 \mathrm{~mL} \mathrm{~min}{ }^{-1}$ of a mixture of hexane/ethyl 
acetate (90:10). Melting point: $210{ }^{\circ} \mathrm{C}$ with decomposition. Yield: $61 \%$ (54.9 mg). ${ }^{1} \mathrm{H}$ NMR (400 MHz, acetone- $\left.\mathrm{d}_{6}\right): \delta 7.28(\mathrm{~d}$, $\left.2 \mathrm{H}, \mathrm{H}_{\mathrm{Ar}}\right) ; 6.93$ (d, 2H, $\mathrm{H}_{\mathrm{Ar}}$ ); 4.15-4.12 (m, 3H, $\left.\mathrm{H}_{\text {cubyl }}\right) ; 3.98-3.95$ $\left(\mathrm{m}, 3 \mathrm{H}, \mathrm{H}_{\text {cubyl }}\right) ; 3.80\left(\mathrm{~s}, 3 \mathrm{H}, \mathrm{CH}_{3}\right) ; 3.65\left(\mathrm{~s}, 3 \mathrm{H}, \mathrm{CH}_{3}\right) .{ }^{13} \mathrm{C} \mathrm{NMR}$ (acetone- $\left.\mathrm{d}_{6}\right): \delta 171.9(\mathrm{q}, \mathrm{C}=\mathrm{O}) ; 160.3\left(\mathrm{q}, \mathrm{C}_{\mathrm{Ar}}-\mathrm{O}\right) ; 133.8\left(2 \mathrm{C}, \mathrm{C}_{\mathrm{Ar}^{-}}\right.$ $\mathrm{H}) ; 125.0\left(\mathrm{q}, \mathrm{C}_{\mathrm{Ar}}-\mathrm{S}\right) ; 115.7\left(2 \mathrm{C}, \mathrm{C}_{\mathrm{Ar}}-\mathrm{H}\right) ; 62.5$ (q, $\left.\mathrm{C}_{\text {cubyl }}-\mathrm{S}\right) ; 57.3$ (q, $\left.\mathrm{C}_{\text {cubyl }}\right) ; 55.7\left(\mathrm{CH}_{3}\right) ; 51.6\left(\mathrm{CH}_{3}\right) ; 50.2\left(3 \mathrm{C}, \mathrm{C}_{\text {cubyl }}-\mathrm{H}\right) ; 47.1$ (3C, $\left.\mathrm{C}_{\text {cubyl }}-\mathrm{H}\right)$. For more details in the assignment and 2D NMR experiments, see ESI. $\dagger$ IR (neat): $\nu=2993,2946,1724(\mathrm{C}=\mathrm{O})$, 1581, 1479, 1436, 1325, 1228, 1198, 1089, 837, 739 and $691 \mathrm{~cm}^{-1}$. HRMS (ESI-TOF) $\mathrm{m} / z$ : $[\mathrm{M}+\mathrm{H}]^{+}$calcd. for $\mathrm{C}_{17} \mathrm{H}_{17} \mathrm{O}_{3} \mathrm{~S}$ 301.0893; found 301.0913 .

\section{Methyl-4-(phenylthio)cubane-1-carboxylate (8)}

The compound was isolated by semi-preparative HPLC, employing a constant flow of $2.0 \mathrm{~mL} \min ^{-1}$ of a mixture of hexane/ethyl acetate $(90: 10)$. Melting point: $198{ }^{\circ} \mathrm{C}$ with decomposition. Yield: $75 \%(60.8 \mathrm{mg}) .{ }^{1} \mathrm{H}$ NMR $(400 \mathrm{MHz}$, acetone- $\left.\mathrm{d}_{6}\right): \delta$ 7.35-7.32 (m, $\left.2 \mathrm{H}, \mathrm{H}_{\mathrm{Ar}}\right) ; 7.24-7.20\left(\mathrm{~m}, 3 \mathrm{H}, \mathrm{H}_{\mathrm{Ar}}\right)$; 4.25-4.22 (m, 3H, $\left.\mathrm{H}_{\text {cubyl }}\right)$; 4.07-4.04 (m, 3H, $\left.\mathrm{H}_{\text {cubyl }}\right) ; 3.66(\mathrm{~s}, 3 \mathrm{H}$, $\left.\mathrm{CH}_{3}\right) .{ }^{13} \mathrm{C}$ NMR (acetone- $\left.\mathrm{d}_{6}\right): \delta 171.9(\mathrm{q}, \mathrm{C}=\mathrm{O}) ; 136.2\left(\mathrm{q}, \mathrm{C}_{\mathrm{Ar}}-\mathrm{S}\right)$; $130.7\left(2 \mathrm{C}, \mathrm{C}_{\mathrm{Ar}}-\mathrm{H}\right) ; 129.7\left(\mathrm{C}_{\mathrm{Ar}}-\mathrm{H}\right) ; 126.9\left(2 \mathrm{C}, \mathrm{C}_{\mathrm{Ar}}-\mathrm{H}\right) ; 61.3$ (q, $\left.\mathrm{C}_{\text {cubyl }}-\mathrm{S}\right) ; 56.9$ (q, $\left.\mathrm{C}_{\text {cubyl }}\right) ; 51.7\left(\mathrm{CH}_{3}\right) ; 50.3\left(3 \mathrm{C}, \mathrm{C}_{\text {cubyl }}-\mathrm{H}\right) ; 47.4$ $\left(3 \mathrm{C}, \mathrm{C}_{\text {cubyl }}-\mathrm{H}\right)$. For more details in the assignment and 2D NMR experiments, see ESI. $\dagger$ HRMS (ESI-TOF) $m / z:[\mathrm{M}+\mathrm{H}]^{+}$calcd. for $\mathrm{C}_{16} \mathrm{H}_{15} \mathrm{O}_{2} \mathrm{~S}$ 271.0787; found: 271.0787 .

\section{Methyl-4-(4-methylphenylthio)cubane-1-carboxylate (9)}

The compound was isolated from the crude by column chromatography, employing a linear gradient of eluent composed of pentane and diethyl ether, from $0 \%$ to $30 \%$ of diethyl ether. Melting point: $201{ }^{\circ} \mathrm{C}$ with decomposition. Yield: $49 \%(41.8$ $\mathrm{mg}) .{ }^{1} \mathrm{H}$ NMR (400 MHz, acetone- $\left.\mathrm{d}_{6}\right): \delta 7.15(\mathrm{~d}, J=2.2 \mathrm{~Hz}, 4 \mathrm{H})$; 4.21-4.18 (m, 3H, $\left.\mathrm{H}_{\text {cubyl }}\right)$; 4.02-3.99 (m, 3H, $\left.\mathrm{H}_{\text {cubyl }}\right) ; 3.65(\mathrm{~s}, 3 \mathrm{H}$, $\left.\mathrm{CH}_{3}\right) ; 2.29$ (s, 3H, $\left.\mathrm{CH}_{3}\right) .{ }^{13} \mathrm{C} \mathrm{NMR}$ (acetone- $\left.\mathrm{d}_{6}\right): \delta 171.9(\mathrm{q}, \mathrm{C}=\mathrm{O})$; 137.0 (q, $\left.\mathrm{C}_{\mathrm{Ar}}-\mathrm{S}\right) ; 132.1$ (q, $\left.\mathrm{C}_{\mathrm{Ar}}\right) ; 130.7\left(2 \mathrm{C}, \mathrm{C}_{\mathrm{Ar}}-\mathrm{H}\right) ; 130.5\left(2 \mathrm{C}, \mathrm{C}_{\mathrm{Ar}^{-}}\right.$ $\mathrm{H}) ; 61.6\left(\mathrm{q}, \mathrm{C}_{\text {cubyl }}-\mathrm{S}\right) ; 56.9$ (q, $\left.\mathrm{C}_{\text {cubyl }}\right) ; 51.6\left(\mathrm{OCH}_{3}\right) ; 50.3\left(\mathrm{C}_{\text {cubyl }^{-}}\right.$ $\mathrm{H}) ; 47.3\left(\mathrm{C}_{\text {cubyl }}-\mathrm{H}\right), 20.9\left(\mathrm{CH}_{3}\right)$. HRMS (ESI-TOF) $m / z:[\mathrm{M}+\mathrm{H}]^{+}$ calcd. for $\mathrm{C}_{17} \mathrm{H}_{17} \mathrm{O}_{2} \mathrm{~S}$ 285.0943; found: 285.0943.

\section{4-(Diphenylphosphoryl)cubane-1-carboxylic acid (10a)}

The cubane analogue was isolated as the derivated acid form of the product 9 from the crude by column chromatography, employing a linear gradient of eluent composed by pentane and diethyl ether, from $10 \%$ to $100 \%$ of diethyl ether. Yield: $21 \%$ (21.9 mg). ${ }^{1} \mathrm{H}$ NMR (400 MHz, dimethyl sulfoxide- ${ }_{6}$ ): $\delta 12.46$ (bb, 1H, OH); 7.62-7.54 (m, 10H); 4.21-4.19 (m, 6H, $\left.\mathrm{H}_{\text {cubyl }}\right) .{ }^{13} \mathrm{C}$ NMR (dimethyl sulfoxide- $\mathrm{d}_{6}$ ): $\delta 171.7(\mathrm{q}, \mathrm{C}=\mathrm{O}) ; 131.9\left(2 \mathrm{C}, \mathrm{d},{ }^{4} J_{\mathrm{P}-}\right.$ $\left.\mathrm{C}=2.4 \mathrm{~Hz}, \mathrm{C}_{\mathrm{Ar}}-\mathrm{H}\right) ; 131.7\left(2 \mathrm{C}, \mathrm{d},{ }^{1} J_{\mathrm{P}-\mathrm{C}}=98.4 \mathrm{~Hz}, \mathrm{q}\right) ; 130.4(4 \mathrm{C}, \mathrm{d}$, $\left.{ }^{3} J_{\mathrm{P}-\mathrm{C}}=9.3 \mathrm{~Hz}, \mathrm{C}_{\mathrm{Ar}}-\mathrm{H}\right) ; 128.9\left(4 \mathrm{C}, \mathrm{d},{ }^{2} J_{\mathrm{P}-\mathrm{C}}=11.3 \mathrm{~Hz}, \mathrm{C}_{\mathrm{Ar}}-\mathrm{H}\right) ; 55.5$ $\left(\mathrm{d},{ }^{4} J_{\mathrm{P}-\mathrm{C}}=4.3 \mathrm{~Hz}, \mathrm{q}, \mathrm{C}_{\text {cubyl }}\right) ; 52.4\left(\mathrm{~d},{ }^{1} J_{\mathrm{P}-\mathrm{C}}=67.4 \mathrm{~Hz}, \mathrm{q}, \mathrm{C}_{\text {cubyl }}\right)$; $47.5\left(3 \mathrm{C}, \mathrm{d},{ }^{2} J_{\mathrm{P}-\mathrm{C}}=8.2 \mathrm{~Hz}, \mathrm{C}_{\text {cubyl }}-\mathrm{H}\right) ; 44.3\left(3 \mathrm{C}, \mathrm{d},{ }^{3} J_{\mathrm{P}-\mathrm{C}}=5.2 \mathrm{~Hz}\right.$, $\mathrm{C}_{\text {cubyl }}-\mathrm{H}$ ). HRMS (ESI-TOF) $\mathrm{m} / \mathrm{z}:[\mathrm{M}-\mathrm{H}]^{-}$calcd. for $\mathrm{C}_{21} \mathrm{H}_{16} \mathrm{O}_{3} \mathrm{P}-$ 347.0843; found: 347.0839 .

\section{1,4-Bis((4-methoxyphenyl)thio)cubane (12a)}

Isolated as a white solid from the crude by column chromatography, employing a linear gradient of eluent composed by pentane and diethyl ether, from $0 \%$ to $30 \%$ of diethyl ether. Melting point: $237{ }^{\circ} \mathrm{C}$ with decomposition. Yield: $48 \%$ in $\mathrm{NH}_{3(\mathrm{l})}$ $(51.3 \mathrm{mg}) .{ }^{1} \mathrm{H}$ NMR (400 MHz, $\left.\mathrm{CDCl}_{3}\right): \delta 7.22(\mathrm{~d}, J=8.8 \mathrm{~Hz}, 4 \mathrm{H})$; $6.83(\mathrm{~d}, J=8.8 \mathrm{~Hz}, 4 \mathrm{H}) ; 3.93\left(\mathrm{~s}, 6 \mathrm{H}, \mathrm{H}_{\mathrm{Cubyl}}\right) ; 3.78\left(\mathrm{~s}, 6 \mathrm{H}, \mathrm{CH}_{3}\right) .{ }^{13} \mathrm{C}$ NMR $\left(\mathrm{CDCl}_{3}\right)$ : $\delta 159.1$ (q, 2C, $\left.\mathrm{C}_{\mathrm{Ar}}-\mathrm{O}\right) ; 132.9\left(4 \mathrm{C}, \mathrm{C}_{\mathrm{Ar}}-\mathrm{H}\right) ; 124.6$ (2C, q, $\left.\mathrm{C}_{\mathrm{Ar}}-\mathrm{S}\right) ; 114.7\left(4 \mathrm{C}, \mathrm{C}_{\mathrm{Ar}}-\mathrm{H}\right) ; 61.8$ (2C, q, $\left.\mathrm{C}_{\text {cubyl }}-\mathrm{S}\right) ; 55.4$ (2C, $\left.\mathrm{CH}_{3}\right) ; 49.0$ (6C, $\mathrm{C}_{\text {cubyl }}-\mathrm{H}$ ). HRMS (ESI-TOF) $m / z:[\mathrm{M}+\mathrm{Na}]^{+}$calcd. for $\mathrm{C}_{22} \mathrm{H}_{20} \mathrm{O}_{2} \mathrm{~S}_{2} \mathrm{Na}$ 403.0797; found 403.0797.

\section{1,4-Bis(phenylthio)cubane (12b)}

The cubane derivative was isolated as a white solid from the crude by column chromatography. Employed was a linear gradient of eluent composed by pentane and diethyl ether, from $0 \%$ to $20 \%$ of diethyl ether. Melting point: $230{ }^{\circ} \mathrm{C}$ with decomposition. Yield: 47\% (42.3 mg). ${ }^{1} \mathrm{H}$ NMR $(400 \mathrm{MHz}$, $\left.\mathrm{CDCl}_{3}\right): \delta$ 7.30-7.26 (m, 4H); 7.20-7.16 (m, 6H); $4.09(\mathrm{~s}, 6 \mathrm{H}$, $\left.\mathrm{H}_{\text {Cubyl }}\right) .{ }^{13} \mathrm{C} \mathrm{NMR}\left(\mathrm{CDCl}_{3}\right): \delta 135.5\left(2 \mathrm{C}, \mathrm{q}, \mathrm{C}_{\mathrm{Ar}}-\mathrm{S}\right) ; 129.2\left(4 \mathrm{C}, \mathrm{C}_{\mathrm{Ar}^{-}}\right.$ $\mathrm{H})$; 129.1 (4C, $\left.\mathrm{C}_{\mathrm{Ar}}-\mathrm{H}\right)$; 126.1 (2C, $\left.\mathrm{C}_{\mathrm{Ar}}-\mathrm{H}\right) ; 60.5$ (2C, q, $\left.\mathrm{C}_{\text {cubyl }}-\mathrm{S}\right)$; 49.5 (6C, $\left.\mathrm{C}_{\text {cubyl }}-\mathrm{H}\right)$. IR (neat): $\nu=3072,3059,2990,1582,1480$, 1435, 1191, 1088, 1069, 732 and $691 \mathrm{~cm}^{-1}$. HRMS (ESI-TOF) $\mathrm{m} / \mathrm{z}$ : $[\mathrm{M}+\mathrm{Na}]^{+}$calcd. for $\mathrm{C}_{20} \mathrm{H}_{16} \mathrm{~S}_{2} \mathrm{Na}$ 343.0586; found 343.0586.

\section{(4-Iodocuban-1-yl)(4-methoxyphenyl)sulfane (13a)}

Isolated as a pale yellow solid from the crude by column chromatography, employing a linear gradient of eluent composed by pentane and diethyl ether, from $0 \%$ to $30 \%$ of diethyl ether. Melting point: $256{ }^{\circ} \mathrm{C}$ with decomposition. Yield: $9 \%$ (9.9 mg). ${ }^{1} \mathrm{H}$ NMR (400 MHz, $\left.\mathrm{CDCl}_{3}\right): \delta 7.21(\mathrm{~d}, J=8.7 \mathrm{~Hz}, 2 \mathrm{H}) ; 6.84(\mathrm{~d}, J=$ 8.7 Hz, 2H); 4.22-4.20 (m, 3H, $\mathrm{H}_{\text {Cubyl }}$ ); 4.13-4.11 (m, 3H, $\mathrm{H}_{\text {Cubyl }}$ ); $3.80\left(\mathrm{~s}, 3 \mathrm{H}, \mathrm{CH}_{3}\right) .{ }^{13} \mathrm{C} \mathrm{NMR}\left(\mathrm{CDCl}_{3}\right): \delta 159.3\left(\mathrm{q}, \mathrm{C}_{\mathrm{Ar}}-\mathrm{O}\right) ; 133.2(2 \mathrm{C}$, $\mathrm{C}_{\mathrm{Ar}}-\mathrm{H}$ ); 124.0 (q, $\left.\mathrm{C}_{\mathrm{Ar}}-\mathrm{S}\right) ; 114.9\left(2 \mathrm{C}, \mathrm{C}_{\mathrm{Ar}}-\mathrm{H}\right) ; 62.2$ (q, $\mathrm{C}_{\text {cubyl }}-\mathrm{S}$ ); $55.5\left(\mathrm{CH}_{3}\right) ; 54.4\left(3 \mathrm{C}, \mathrm{C}_{\text {cubyl }}-\mathrm{H}\right) ; 52.6\left(3 \mathrm{C}, \mathrm{C}_{\text {cubyl }}-\mathrm{H}\right), 37.1$ (q, $\mathrm{C}_{\text {cubyl }}-\mathrm{I}$ ). HRMS (ESI-TOF) $m / z:[\mathrm{M}+\mathrm{H}]^{+}$calcd. for $\mathrm{C}_{15} \mathrm{H}_{14} \mathrm{IOS}$ 368.9805; found: 368.9805 .

\section{(4-Iodocuban-1-yl)(phenyl)sulfane (13b)}

The cubane compound was isolated as a pale yellow solid from the crude by column chromatography, employing a linear gradient of eluent composed by pentane and diethyl ether, from $0 \%$ to $20 \%$ of diethyl ether. Melting point: $251{ }^{\circ} \mathrm{C}$ with decomposition. Yield: $15 \%(14.2 \mathrm{mg}) .{ }^{1} \mathrm{H}$ NMR $(400 \mathrm{MHz}$, $\left.\mathrm{CDCl}_{3}\right): \delta 7.30-7.13(\mathrm{~m}, 5 \mathrm{H}) ; 4.31-4.28\left(\mathrm{~m}, 3 \mathrm{H}, \mathrm{H}_{\text {Cubyl }}\right) ; 4.23-4.20$ $\left(\mathrm{m}, 3 \mathrm{H}, \mathrm{H}_{\text {Cubyl }}\right) .{ }^{13} \mathrm{C} \mathrm{NMR}\left(\mathrm{CDCl}_{3}\right): \delta 135.1$ (q, $\left.\mathrm{C}_{\mathrm{Ar}}-\mathrm{S}\right) ; 129.25(2 \mathrm{C}$, $\left.\mathrm{C}_{\mathrm{Ar}}-\mathrm{H}\right) ; 129.23\left(2 \mathrm{C}, \mathrm{C}_{\mathrm{Ar}}-\mathrm{H}\right) ; 126.3\left(\mathrm{C}_{\mathrm{Ar}}-\mathrm{H}\right) ; 61.1$ (q, $\left.\mathrm{C}_{\text {cubyl }}-\mathrm{S}\right) ; 54.7$ (3C, $\left.\mathrm{C}_{\text {cubyl }}-\mathrm{H}\right) ; 52.7$ (3C, $\left.\mathrm{C}_{\text {cubyl }}-\mathrm{H}\right) ; 36.5$ (q, $\left.\mathrm{C}_{\text {cubyl }}-\mathrm{I}\right)$. HRMS (ESITOF) $m / z:[\mathrm{M}+\mathrm{H}]^{+}$calcd. for $\mathrm{C}_{14} \mathrm{H}_{11} \mathrm{IS} 338.9699$; found 338.9683 .

\section{(4-Iodocuban-1-yl)(naphthalen-2-yl)sulfane (13c)}

Isolated as a white solid from the crude by semi-preparative HPLC, employing as eluent of acetonitrile/water at a ratio of 90 : 10 and constant flow of $2 \mathrm{~mL} \mathrm{~min}^{-1}$. Melting point: $261{ }^{\circ} \mathrm{C}$ 
with decomposition. Yield: $12 \%(13.1 \mathrm{mg}) .{ }^{1} \mathrm{HNMR}(400 \mathrm{MHz}$, $\left.\mathrm{CDCl}_{3}\right): \delta 7.80-7.70(\mathrm{~m}, 3 \mathrm{H}) ; 7.52(\mathrm{~s}, 1 \mathrm{H}) ; 7.50-7.42(\mathrm{~m}, 2 \mathrm{H}) ;$ 7.29-7.26 (m, $1 \mathrm{H})$; 4.35-4.33 (m, 3H, $\left.\mathrm{H}_{\text {cubyl }}\right) ; 4.29-4.27(\mathrm{~m}, 3 \mathrm{H}$, $\left.\mathrm{H}_{\text {cubyl }}\right) \cdot{ }^{13} \mathrm{C}-\mathrm{NMR}\left(\mathrm{CDCl}_{3}\right): \delta 133.9\left(\mathrm{q}, \mathrm{C}_{\mathrm{Ar}}-\mathrm{S}\right) ; 132.6\left(\mathrm{q}, \mathrm{C}_{\mathrm{Ar}}\right) ; 131.9$ (q, $\left.\mathrm{C}_{\mathrm{Ar}}\right) ; 128.8\left(\mathrm{C}_{\mathrm{Ar}}-\mathrm{H}\right) ; 127.9\left(\mathrm{C}_{\mathrm{Ar}}-\mathrm{H}\right) ; 127.4\left(\mathrm{C}_{\mathrm{Ar}}-\mathrm{H}\right) ; 127.3\left(\mathrm{C}_{\mathrm{Ar}^{-}}\right.$ $\mathrm{H}) ; 127.3\left(\mathrm{C}_{\mathrm{Ar}}-\mathrm{H}\right) ; 126.8\left(\mathrm{C}_{\mathrm{Ar}}-\mathrm{H}\right) ; 125.9\left(\mathrm{C}_{\mathrm{Ar}}-\mathrm{H}\right) ; 61.2\left(\mathrm{q}, \mathrm{C}_{\text {cubyl }^{-}}\right.$ $\mathrm{S}) ; 54.8\left(3 \mathrm{C}, \mathrm{C}_{\text {cubyl }}-\mathrm{H}\right) ; 52.8\left(3 \mathrm{C}, \mathrm{C}_{\text {cubyl }}-\mathrm{H}\right) ; 36.5$ (q, $\left.\mathrm{C}_{\text {cubyl }}-\mathrm{I}\right)$. HRMS (ESI-TOF) $m / z$ : $[\mathrm{M}+\mathrm{H}]^{+}$calcd. for $\mathrm{C}_{18} \mathrm{H}_{14} \mathrm{IS} 388.9855$; found: 388.9858 .

\section{Cuban-1-yl(4-methoxyphenyl)sulfane (14a)}

Isolated as a white solid from the crude by column chromatography, employing a linear gradient of eluent composed by pentane and diethyl ether, from $0 \%$ to $30 \%$ of diethyl ether. Melting point: $226{ }^{\circ} \mathrm{C}$ with decomposition. Yield: $10 \%(6.8 \mathrm{mg})$. ${ }^{1} \mathrm{H}$ NMR (400 MHz, $\left.\mathrm{CDCl}_{3}\right): \delta 7.20(\mathrm{dt}, J=8.8 \mathrm{~Hz}, 2 \mathrm{H}) ; 6.84(\mathrm{dt}, J$ $=8.8 \mathrm{~Hz}, 2 \mathrm{H}) ; 4.07-4.00\left(\mathrm{~m}, 4 \mathrm{H}, \mathrm{H}_{\text {Cubyl }}\right) ; 3.99-3.95(\mathrm{~m}, 3 \mathrm{H}$, $\mathrm{H}_{\text {Cubyl }}$ ); $3.79\left(\mathrm{~s}, 3 \mathrm{H}, \mathrm{CH}_{3}\right) .{ }^{13} \mathrm{C} \mathrm{NMR}\left(\mathrm{CDCl}_{3}\right): \delta 158.8\left(\mathrm{q}, \mathrm{C}_{\mathrm{Ar}}-\mathrm{O}\right)$; 132.3 (2C, $\left.\mathrm{C}_{\mathrm{Ar}}-\mathrm{H}\right) ; 125.7$ (q, $\left.\mathrm{C}_{\mathrm{Ar}}-\mathrm{S}\right) ; 114.7$ (2C, $\left.\mathrm{C}_{\mathrm{Ar}}-\mathrm{H}\right) ; 60.9$ (q, $\left.\mathrm{C}_{\text {cubyl }}-\mathrm{S}\right) ; 55.4\left(\mathrm{CH}_{3}\right) ; 52.2\left(3 \mathrm{C}, \mathrm{C}_{\text {cubyl }}-\mathrm{H}\right) ; 48.3$ (q, $\left.\mathrm{C}_{\text {cubyl }}-\mathrm{S}\right) ; 44.8$ $\left(3 \mathrm{C}, \mathrm{C}_{\text {cubyl }}-\mathrm{H}\right)$. For more details in the assignment and 2D NMR experiments, see ESI. $\dagger$ HRMS (ESI-TOF) $m / z:[\mathrm{M}+\mathrm{H}]^{+}$calcd. for $\mathrm{C}_{15} \mathrm{H}_{15} \mathrm{OS} 243.0838$; found: 243.0853 .

\section{Cuban-1-yl(phenyl)sulfane (14b)}

Isolated as a pale brown solid from the crude by column chromatography, employing a linear gradient of eluent composed by pentane and diethyl ether, from $0 \%$ to $20 \%$ of diethyl ether. Melting point: $300{ }^{\circ} \mathrm{C}$ with decomposition. Yield: $8 \%(5.4 \mathrm{mg})$. ${ }^{1} \mathrm{H}$ NMR (400 MHz, $\left.\mathrm{CDCl}_{3}\right): \delta 7.29-7.25(\mathrm{~m}, 2 \mathrm{H}) ; 7.17-7.13(\mathrm{~m}$, $3 \mathrm{H})$; 4.12-4.05 (m, 7H, $\left.\mathrm{H}_{\text {Cubyl }}\right){ }^{13} \mathrm{C} \mathrm{NMR}\left(\mathrm{CDCl}_{3}\right): \delta 136.6\left(\mathrm{q}, \mathrm{C}_{\mathrm{Ar}^{-}}\right.$ $\mathrm{S}) ; 129.1\left(2 \mathrm{C}, \mathrm{C}_{\mathrm{Ar}}-\mathrm{H}\right) ; 128.5\left(2 \mathrm{C}, \mathrm{C}_{\mathrm{Ar}}-\mathrm{H}\right) ; 125.5\left(\mathrm{C}_{\mathrm{Ar}}-\mathrm{H}\right) ; 57.0$ (q, $\left.\mathrm{C}_{\text {cubyl }}-\mathrm{S}\right) ; 52.3\left(3 \mathrm{C}, \mathrm{C}_{\text {cubyl }}-\mathrm{H}\right) ; 47.9\left(\mathrm{C}_{\text {cubyl }}-\mathrm{H}\right) ; 45.1\left(3 \mathrm{C}, \mathrm{C}_{\text {cubyl }}-\mathrm{H}\right)$. HRMS (ESI-TOF) $m / z$ : $[\mathrm{M}+\mathrm{H}]^{+}$calcd. for $\mathrm{C}_{15} \mathrm{H}_{15} \mathrm{OS} 243.0838$; found: 243.0853 .

\section{Cuban-1-yl-diphenylphosphine oxide (14d)}

The cubane derivative was isolated as a white solid from the crude by column chromatography (gradient from pentane to ethyl acetate $100 \%$ ) followed by semi-preparative HPLC, employing a mixture of pentane/isopropanol (gradient from $100 \%$ of pentane to $40 \%$ isopropanol at the end) at constant flow of $2 \mathrm{~mL} \mathrm{~min}^{-1}$. Melting point: nd. $>300{ }^{\circ} \mathrm{C}$. Yield: $18 \%(15.4$ mg). ${ }^{1} \mathrm{H}$ NMR (400 MHz, $\left.\mathrm{CDCl}_{3}\right): \delta 7.64-7.59(\mathrm{~m}, 4 \mathrm{H}) ; 7.54-7.50$ (m, 2H); 7.47-7.43 (m, 4H); 4.35-4.30 (m, 3H, $\mathrm{H}_{\text {Cubyl }}$ ); 4.12-4.05 $\left(\mathrm{m}, 4 \mathrm{H}, \mathrm{H}_{\text {Cubyl }}\right) .{ }^{13} \mathrm{C} \mathrm{NMR}\left(\mathrm{CDCl}_{3}\right): \delta 132.0\left(2 \mathrm{C}, \mathrm{d},{ }^{1} J_{\mathrm{P}-\mathrm{C}}=99.5 \mathrm{~Hz}\right.$, $\left.\mathrm{q}, \mathrm{C}_{\mathrm{Ar}}\right) ; 131.8\left(2 \mathrm{C}, \mathrm{d},{ }^{4} J_{\mathrm{P}-\mathrm{C}}=2.7 \mathrm{~Hz}, \mathrm{C}_{\mathrm{Ar}}-\mathrm{H}\right) ; 131.0\left(4 \mathrm{C}, \mathrm{d},{ }^{3} J_{\mathrm{P}-\mathrm{C}}=\right.$ $\left.9.4 \mathrm{~Hz}, \mathrm{C}_{\mathrm{Ar}}-\mathrm{H}\right) ; 128.8\left(4 \mathrm{C}, \mathrm{d},{ }^{2} J_{\mathrm{P}-\mathrm{C}}=11.5 \mathrm{~Hz}, \mathrm{C}_{\mathrm{Ar}}-\mathrm{H}\right) ; 52.5\left(\mathrm{~d},{ }^{1} J_{\mathrm{P}-\mathrm{C}}\right.$ $\left.=66.1 \mathrm{~Hz}, \mathrm{q}, \mathrm{C}_{\text {cubyl }}\right) ; 47.9\left(\mathrm{~d},{ }^{4} J_{\mathrm{P}-\mathrm{C}}=5.0 \mathrm{~Hz}, \mathrm{C}_{\text {cubyl }}-\mathrm{H}\right) ; 47.8(3 \mathrm{C}$, $\left.\mathrm{d},{ }^{3} J_{\mathrm{P}-\mathrm{C}}=5.8 \mathrm{~Hz}, \mathrm{C}_{\text {cubyl }}-\mathrm{H}\right) ; 46.8\left(3 \mathrm{C}, \mathrm{d},{ }^{2} J_{\mathrm{P}-\mathrm{C}}=8.0 \mathrm{~Hz}, \mathrm{C}_{\text {cubyl }}-\mathrm{H}\right)$. IR (neat): $\nu=3056,2989,1437$ (P-C deformation band), 1220, 1178, 1116, 722, 700, 554 and $523\left(\mathrm{~cm}^{-1}\right)$. HRMS (ESI-TOF) $\mathrm{m} / \mathrm{z}$ : $[\mathrm{M}+\mathrm{H}]^{+}$calcd. for $\mathrm{C}_{20} \mathrm{H}_{18} \mathrm{OP}$ 305.1090; found: 305.1086.

\section{Conflicts of interest}

There are no conflicts to declare.

\section{Acknowledgements}

This work was partly supported by the Consejo Nacional de Investigaciones Científicas y Técnicas (CONICET), Secretaría de Ciencia y Tecnología, Universidad Nacional de Córdoba (SECyT), and the Agencia Nacional de Promoción Científica y Técnica (ANPCyT). L. B. Jimenez thanks to Dr Lucas Peisino for his experimental help. K. F. C. A. gratefully acknowledges a fellowship from CONICET.

\section{Notes and references}

1 R. A. Rossi, A. B. Pierini and A. B. Peñéñory, Chem. Rev., 2003, 103, 71.

2 J. I. Bardagí, V. A. Vaillard and R. A. Rossi, in Encyclopedia of Radicals in Chemistry, Biology \& Materials, ed. C. Chatgilialoglu and A. Studer, John Wiley \& Sons Ltd., Chichester, UK, 2012, vol. 1, p. 333.

3 M. Ahbala, P. Hapiot, A. Houmam, M. Jouini, J. Pinson and J.-M. Savéant, J. Am. Chem. Soc., 1995, 117, 11488.

4 (a) A. N. Santiago, V. S. Iyer, W. Adcock and R. A. Rossi, J. Org. Chem., 1988, 53, 3016; (b) W. Adcock, C. I. Clark and N. A. Trout, J. Org. Chem., 2001, 66, 3362.

5 (a) P. Eaton and T. W. J. Cole, J. Am. Chem. Soc., 1964, 86, 962; (b) P. Eaton and T. W. J. Cole, J. Am. Chem. Soc., 1964, 86, 3158.

6 K. F. Biegasiewicz, J. R. Griffiths, G. P. Savage, J. Tsanaktsidis and R. Priefer, Chem. Rev., 2015, 115, 6719.

7 (a) A. A. Fokin, O. Lauenstein, P. A. Gunchenki and P. R. Schreiner, J. Am. Chem. Soc., 2001, 123, 1842; (b) A. Bashir-Hashemi, J. Li, N. Gelber and H. J. Ammon, J. Org. Chem., 1995, 60, 698; (c) S. Plunkett, K. J. Flanagan, B. Twamley and M. O. Senge, Organometallics, 2015, 34, 1408; (d) J. Wlochal, R. D. M. Davies and J. Burton, Org. Lett., 2014, 16, 4094.

8 (a) P. E. Eaton, Angew. Chem., Int. Ed. Engl., 1992, 31, 1421; (b) A. Bashir-Hashemi and H. Higuchi, in The Chemistry of Functional Groups. The Chemistry of Cyclobutanes, ed. Z. Rappoport and J. F. Liebman, John Wiley \& Sons, 2005, ch. 19.

9 R. Priefer, S. Nguyen, P. G. Farrell and D. N. Harpp, Macromolecules, 2003, 36, 5435.

10 (a) K. F. Biegasiewicz, M. L. Ingalsbe, J. D. St. Denis, J. L. Gleason, J. Ho, M. L. Coote, G. P. Savage and R. Priefer, Beilstein J. Org. Chem., 2012, 8, 1814; (b) M. L. Ingalsbe, J. D. St. Denis, J. L. Gleason, G. P. Savage and R. Priefer, Synthesis, 2010, 98; (c) R. F. Service, Science, 2000, 287, 564; (d) D. A. Hrovat, W. T. Borden, P. E. Eaton and B. Kahr, J. Am. Chem. Soc., 2001, 123, 1289; (e) G. Y. Bénye, I. Jalsovszky, C. Slugovc, G. Trimmel, G. Pelzl, A. Vajda, N. Éber and K. Fodor-Csorba, Liq. Cryst., 2005, 32, 197; $(f)$ V. V. Chaban and O. V. Prezhdo, ACS Energy Lett., 2016, 1, 189. 
11 (a) S. S. R. Bernhard, G. M. Locke, S. Plunkett, A. Meindl, K. J. Flanagan and M. O. Senge, Chem.-Eur. J., 2018, 24, 1026; (b) F. Toriyama, J. Cornella, L. Wimmer, T.-G. Chen, D. D. Dixon, G. Creech and P. S. Baran, J. Am. Chem. Soc., 2016, 138, 11132.

12 G. W. Griffin and A. P. Marchand, Chem. Rev., 1989, 89, 997. 13 (a) E. W. Della, N. J. Head, P. Mallon and J. C. Walton, J. Am. Chem. Soc., 1992, 114, 10730; (b) P. E. Eaton, J. Li and S. P. Upadhyaya, J. Org. Chem., 1995, 60, 966; (c) P. E. Eaton and J. Tsanaktsidis, J. Am. Chem. Soc., 1990, 112, 876; (d) J. Ho, J. Zheng, R. Meana-Pañeda, D. G. Truhlar, E. J. Ko, G. P. Savage, C. M. Williams, M. L. Coote and J. Tsanaktsidis, J. Org. Chem., 2013, 78, 6677.

14 R. Priefer, P. G. Farrell and D. N. Harpp, Synthesis, 2002, 2671.

15 (a) P. E. Eaton and J. P. Zhou, J. Am. Chem. Soc., 1992, 114, 3118; (b) E. W. Della and C. H. Schiesser, J. Chem. Soc., Chem. Commun., 1994, 417.

16 (a) H. Hare, T. Emrick, P. E. Eaton and S. R. Kass, J. Am. Chem. Soc., 1997, 119, 237; (b) P. E. Eaton and G. Castaldi, J. Am. Chem. Soc., 1985, 107, 724.

17 J. R. Griffiths, G. P. Savage and R. Priefer, Thermochim. Acta, 2010, 499, 15.

18 (a) V. M. Carroll, D. N. Harpp and R. Priefer, Tetrahedron Lett., 2008, 49, 2677; (b) P. J. Heaphy, J. R. Griffiths, C. J. Dietz, G. P. Savage and R. Priefer, Tetrahedron Lett., 2011, 52, 6359.

19 (a) R. Priefer, Y. J. Lee, F. Barrios, J. H. Wosnick, A.-M. Lebuis, A. Sun, S. Wu, J. P. Snyder, P. G. Farrell and D. N. Harpp, J. Am. Chem. Soc., 2002, 124, 5626; (b) R. Priefer, E. Martineau and D. N. Harpp, J. Sulfur Chem., 2007, 28, 529.

20 R. A. Rossi, A. B. Pierini and A. N. Santiago, in Organic Reactions, ed. L. A. Paquette and R. Bittman, Wiley, New York, 1999, vol. 54, p. 44.

21 S. E. Braslavsky, Pure Appl. Chem., 2007, 79, 335.
22 (a) R. A. Rossi, A. B. Pierini and G. L. Borosky, J. Chem. Soc., Perkin Trans. 2, 1994, 2577; (b) A. E. Lukach, A. N. Santiago and R. A. Rossi, J. Org. Chem., 1997, 62, 4262.

23 (a) S. E. Vaillard, A. Postigo and R. A. Rossi, J. Org. Chem., 2002, 67, 8500; (b) L. E. Peisino and A. B. Pierini, J. Org. Chem., 2013, 78, 4719.

24 A. B. Pierini, A. N. Santiago and R. A. Rossi, Tetrahedron, 1991, 47, 941.

25 J. G. Uranga, D. M. Vera, A. N. Santiago and A. B. Pierini, J. Org. Chem., 2006, 71, 6596.

26 M. J. Frisch, G. W. Trucks, H. B. Schlegel, G. E. Scuseria, M. A. Robb, J. R. Cheeseman, G. Scalmani, V. Barone, B. Mennucci, G. A. Petersson, H. Nakatsuji, M. Caricato, X. Li, H. P. Hratchian, A. F. Izmaylov, J. Bloino, G. Zheng, J. L. Sonnenberg, M. Hada, M. Ehara, K. Toyota, R. Fukuda, J. Hasegawa, M. Ishida, T. Nakajima, Y. Honda, O. Kitao, H. Nakai, T. Vreven, J. A. Montgomery Jr, J. E. Peralta, F. Ogliaro, M. Bearpark, J. J. Heyd, E. Brothers, K. N. Kudin, V. N. Staroverov, R. Kobayashi, J. Normand, K. Raghavachari, A. Rendell, J. C. Burant, S. S. Iyengar, J. Tomasi, M. Cossi, N. Rega, N. J. Millam, M. Klene, J. E. Knox, J. B. Cross, V. Bakken, C. Adamo, J. Jaramillo, R. Gomperts, R. E. Stratmann, O. Yazyev, A. J. Austin, R. Cammi, C. Pomelli, J. W. Ochterski, R. L. Martin, K. Morokuma, V. G. Zakrzewski, G. A. Voth, P. Salvador, J. J. Dannenberg, S. Dapprich, A. D. Daniels, Ö. Farkas, J. B. Foresman, J. V. Ortiz, J. Cioslowski and D. J. Fox, Gaussian 09, Revision E.01, Gaussian, Inc., Wallingford CT, 2009.

27 (a) F. Weigend and R. A. Ahlrichs, Phys. Chem. Chem. Phys., 2005, 7, 3297; (b) F. Weigend, Phys. Chem. Chem. Phys., 2006, 8, 1057.

28 J. Tomasi, B. Mennucci and R. Cammi, Chem. Rev., 2005, 105, 2999.

29 G. Scalmani and M. J. Frisch, J. Chem. Phys., 2010, 132, 114110. 